\title{
Ice volume distribution and implications on runoff projections in a glacierized catchment
}

\author{
J. Gabbi ${ }^{1}$, D. Farinotti ${ }^{1}$, A. Bauder ${ }^{1}$, and H. Maurer ${ }^{2}$ \\ ${ }^{1}$ Laboratory of Hydraulics, Hydrology and Glaciology (VAW), ETH Zurich, Gloriastrasse 37/39, 8092 Zurich, Switzerland \\ ${ }^{2}$ Institute of Geophysics, ETH Zurich, Sonneggstrasse 5, 8092 Zurich, Switzerland
}

Correspondence to: J. Gabbi (gabbij@ vaw.baug.ethz.ch)

Received: 15 May 2012 - Published in Hydrol. Earth Syst. Sci. Discuss.: 13 June 2012

Revised: 29 October 2012 - Accepted: 6 November 2012 - Published: 3 December 2012

\begin{abstract}
A dense network of helicopter-based groundpenetrating radar (GPR) measurements was used to determine the ice-thickness distribution in the Mauvoisin region. The comprehensive set of ice-thickness measurements was combined with an ice-thickness estimation approach for an accurate determination of the bedrock. A total ice volume of $3.69 \pm 0.31 \mathrm{~km}^{3}$ and a maximum ice thickness of $290 \mathrm{~m}$ were found. The ice-thickness values were then employed as input for a combined glacio-hydrological model forced by most recent regional climate scenarios. This model provided glacier evolution and runoff projections for the period 2010-2100. Runoff projections of the measured initial ice volume distribution show an increase in annual runoff of $4 \%$ in the next two decades, followed by a persistent runoff decrease until 2100. Finally, we checked the influence of the ice-thickness distribution on runoff projections. Our analyses revealed that reliable estimates of the ice volume are essential for modelling future glacier and runoff evolution. Wrong estimations of the total ice volume might even lead to deviations of the predicted general runoff trend.
\end{abstract}

\section{Introduction}

The demand for renewable energy is rising, especially when considering the declining confidence in nuclear power and the ascending greenhouse gas emissions (Bundesamt für Energie, 2011a). Particularly in alpine regions with sufficient amounts of precipitation, hydropower is one of the most efficient and appropriate energy sources (Bundesamt für Energie, 2011b). In many high-mountain basins the water supply to hydropower reservoirs primarily consists of melt providing considerable amounts of water even in summer, when precipitation events are rare (Verbunt et al., 2003; Hock et al., 2005). Glaciers act as large freshwater reservoirs accumulating snow during the cold season and releasing the water accumulated as snow and ice during summer. This leads to sustainable differences in the runoff regime of glacierized basins compared to non-glacierized ones (e.g. Chen and Ohmura, 1990). However, the projected climate change and the associated glacier retreat entail the potential risk of serious diminution of the glacial induced water supply (Braun et al., 2000; Huss et al., 2008b; Farinotti et al., 2012).

In recent years, different studies examined the impact of climate change on runoff projections for high-alpine basins (Braun et al., 2000; Verbunt et al., 2003; Horton et al., 2006; Schaefli et al., 2007; Huss et al., 2008b; Farinotti et al., 2012; Uhlmann et al., 2012). Highly glacierized catchments require appropriate modelling of glacial processes including mass balance modelling (Klok and Oerlemans, 2002; Pellicciotti et al., 2005; Huss et al., 2008b) and adaptation of the glacier surface geometry (Vieli et al., 1997; Schneeberger et al., 2003; Huss et al., 2010; Jouvet et al., 2011). The initial ice volume distribution forms the basis for the determination of the glacier and runoff evolution of glacierized catchments. In order to deal with difficulties arising from the scarce or no data availability of the glacier bed, ice-thickness estimation approaches (e.g. Farinotti et al., 2009b; Fischer, 2009; Paul and Linsbauer, 2012) have been developed.

This study focuses on the determination of the glacier bed topography in the Mauvoisin region and the impact of the initial ice volume distribution on runoff projections of high-mountain catchments until 2100. A dense network of helicopter- and ground-based ground-penetrating radar 
(GPR) measurements served as data basis for the determination of the ice-thickness distribution. The ice-thickness measurements were combined with an ice-thickness estimation approach in order to determine the glacier bed topography in the study area as accurately as possible (Sect. 3). Integrating the newly acquired knowledge about the ice volume distribution, the Glacier Evolution and Runoff Model (GERM, Huss et al., 2008b; Farinotti et al., 2012) forced by most recent climate scenarios (Bosshard et al., 2011) was applied to derive glacier evolution and runoff projections until 2100 for the region (Sect. 4). The model approach and the sensitivity of the model parameters have been tested in the study of Farinotti et al. (2012). In the scope of this study, the impact of uncertain ice-thickness estimations, due to a lack of ice-thickness measurements or the usage of inappropriate ice-thickness estimation methods, on runoff projections was analysed (Sect. 5). Uniform ice-thickness distribution, commonly used in macro-scale hydrological models, and more sophisticated results obtained from an ice-thickness estimation method (Farinotti et al., 2009b) deriving the distribution according to the surface topography were considered. Furthermore, the effect of over- or underestimation of the total ice volume was investigated. The main part of the article is divided in three separate sections about (1) the ice-thickness distribution, (2) the glacio-hydrological modelling, and (3) the ice volume sensitivity analysis whereby each section contains the corresponding methods and results.

\section{Study site and data}

The Mauvoisin area is situated in the south-western part of the Valais Alps, Switzerland (Fig. 1). The catchment extends over an area of $150 \mathrm{~km}^{2}$, with $63 \mathrm{~km}^{2}$ covered by glaciers in 2009, accommodating five larger glaciers $\left(5-18 \mathrm{~km}^{2}\right)$ and several smaller glaciers $\left(<5 \mathrm{~km}^{2}\right)$. Due to the northwest orientation of the valley axis, the glaciers show exposures from southwest via north to east. They range in altitude from 2200 to $4300 \mathrm{~m}$ a.s.l. (Table 1 ).

The climate in the Mauvoisin region is characterized by mean precipitation amounts of about $1600 \mathrm{~mm} \mathrm{a}^{-1}$ and a mean annual temperature of $-3.5^{\circ} \mathrm{C}$.

The transient modelling of glacier and runoff evolution in the past and future requires a wide range of different data sets. Past temperature and precipitation time series as well as projections for the future climate are used to force the model (see Sect. 4.1.1). Direct mass balance measurements, decadal ice volume changes derived from topographic maps and areal photographs as well as runoff measurements are used for model calibration (Table 2). Due to long-term efforts, annual mass balance measurements are available since 1966 for Glacier du Giétro and since 1996 for Glacier de Corbassière (Bauder, 2003; Bauder et al., 2007). Digital elevation models (DEMs) of the glacier surface are available for the years 1934, 1983 and 2009 for all glaciers in the

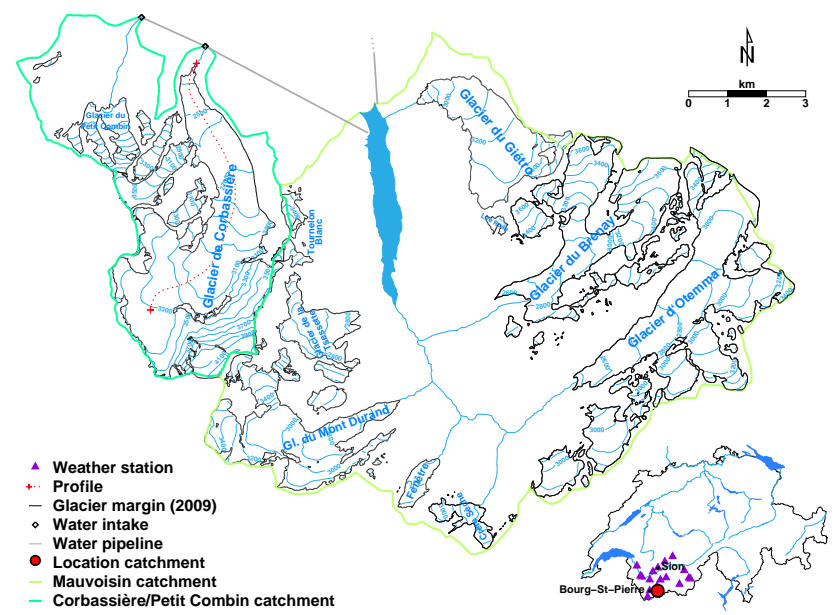

Fig. 1. Overview of the Mauvoisin region. The inset on the bottom right shows the location of the catchment within Switzerland and the weather stations used in this study. The red dashed line refers to the profile of Fig. 11.

catchment. Additional DEMs of the years 1997/1998 and 2003 exist for Glacier de Corbassière and Glacier du Giétro. DEMs of the year 1934 are based on topographic maps, whereas the others are derived by photogrammetrical analysis of areal photographs. An overview on the used data sets is shown in Table 2.

Hydrometric data are available from the hydropower company Mauvoisin since 1982. The data include water level variations of the Mauvoisin reservoir, its outflow and the input of the water conducting pipelines on the left- and righthand side (Fig. 1). Inflow and lake level measurements have monthly resolution for the period 1982 to 2000 and daily resolution since 2000. According to the available runoff data, we divided the basin into two sub-catchments: the Mauvoisin catchment, which corresponds to the natural catchment of the reservoir, and the Corbassière/Petit Combin catchment, which represents the area in the west including Glacier de Corbassière and Glacier du Petit Combin (Fig. 1). The runoff time series of the Mauvoisin catchment were generated by subtracting the inflow from the two pipelines and the outflow of the reservoir from the lake level changes.

\section{Ice-thickness distribution}

\subsection{GPR measurements}

In spring 2011, helicopter-based GPR surveys were carried out on the five largest glaciers in the Mauvoisin region (see Table 2). One-hundred and twenty-two km of GPR profiles were recorded whereof $55 \%$ showed clearly detectable reflections, such that they could be incorporated in the ice volume calculation. The data were acquired by the commercial company RST Radar Systemtechnik GmbH (Salem, 
Table 1. Area, ice volume, altitudinal range and main exposition of the glaciers in the Mauvoisin region. Data refer to 2009.

\begin{tabular}{lrrll}
\hline Glacier & $\begin{array}{r}\text { Area } \\
\mathrm{km}^{2}\end{array}$ & $\begin{array}{r}\text { Volume } \\
\mathrm{km}^{3}\end{array}$ & $\begin{array}{l}\text { Alt. range } \\
\mathrm{m} \text { a.s.l. }\end{array}$ & Expo \\
\hline Corbassière & 18.26 & 1.379 & $2235-4315$ & $\mathrm{~N}$ \\
Otemma & 15.74 & 1.052 & $2465-3815$ & $\mathrm{SW}$ \\
Brenay & 8.99 & 0.384 & $2575-3815$ & $\mathrm{SW}$ \\
Mont Durand & 6.98 & 0.298 & $2360-4160$ & $\mathrm{NE}$ \\
Giétro & 5.46 & 0.447 & $2620-3815$ & $\mathrm{NW}$ \\
Tsessette & 3.05 & 0.076 & $2490-4025$ & $\mathrm{E}$ \\
Petit Combin & 2.53 & 0.023 & $2665-3665$ & $\mathrm{~N}$ \\
Fenêtre & 0.67 & 0.014 & $2575-3150$ & $\mathrm{NE}$ \\
Crête Sèche & 0.60 & 0.009 & $2645-3150$ & $\mathrm{NE}$ \\
Tournelon Blanc & 0.39 & 0.004 & $3140-3690$ & $\mathrm{E}$ \\
Lire Rose & 0.14 & 0.001 & $3095-3225$ & $\mathrm{SW}$ \\
\hline
\end{tabular}

Germany). They employed an acquisition unit operating in a gated stepped mode using frequencies between 50 and $150 \mathrm{MHz}$ (Radar Systemtechnik GmbH, 2012). Additionally, ground-based GPR measurements from previous field campaigns of the years 1988/1998 and 1997 on Glacier de Corbassière and Glacier du Giétro, respectively, were included (Fig. 2, VAW 1998).

\subsubsection{GPR processing}

Visualization of the bedrock topography in the GPR sections required several processing steps to be applied. The helicopter-borne GPR data were acquired more or less continuously during the flights. In a first step, the positions of the GPR signals of the different traces were projected on straight profiles which is required for the further processing of the GPR data. In order to remove the inherent system ringing of GPR acquisition systems, a singular value decomposition based on multichannel filters has been performed. In a next step, a bandpass filter was applied, which removed signal portions outside of the frequency band radiated by the GPR transmitter antenna. Then, the reflected signals from the glacier surface had to be identified in the GPR sections, which allowed static corrections to be applied. A further critical processing step included application of gain functions for enhancing small amplitudes at later times in the radargrams (e.g. bedrock reflections). The signal-to-noise ratio was further improved by defining discrete bins along the profiles and stacking the traces contained in each bin. Finally, a Kirchhoff migration was applied for removing artefacts produced by point scatterers (e.g. large boulders) and to correctly position the reflectors in the individual sections. Figure 3 shows a finally processed section across the Glacier d'Otemma. The bedrock reflection is clearly visible and reaches its maximum depth of about $250 \mathrm{~m}$ at a horizontal distance of $550 \mathrm{~m}$.

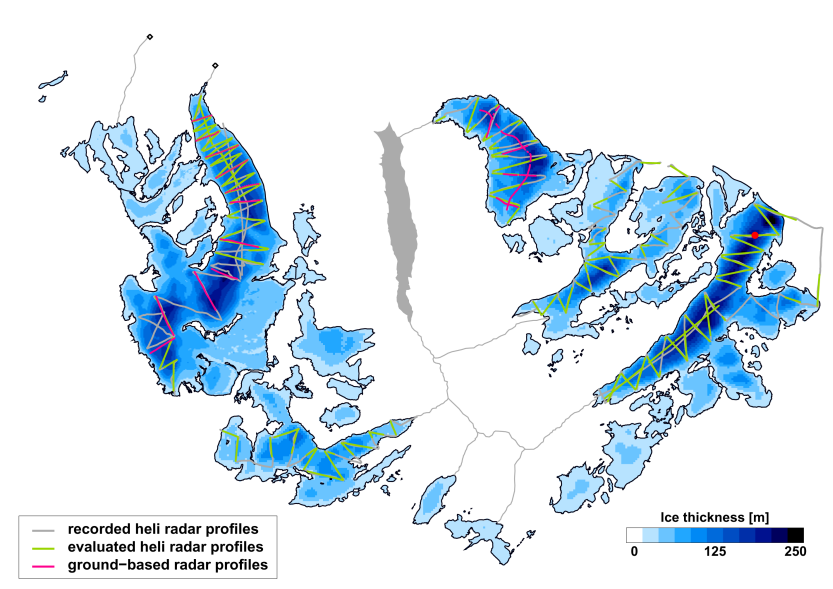

Fig. 2. Ice-thickness distribution in the Mauvoisin region derived by all available ice-thickness measurements. Glacier outlines refer to 2009. The grey lines show the recorded helicopter-based GPR profiles, the green lines the finally evaluated profiles and the red lines the ground-based GPR profiles from previous field campaigns. The red dot refers to the GPR section shown in Fig. 3.

\subsubsection{Uncertainties of GPR measurements}

Uncertainties of the ice-thickness measurements originate from different sources of error. The main uncertainty arises due to blurry reflection horizons. Always the upper boundary of the reflection band was picked. By the identification of the bed reflections, care was taken to ensure that no sharp edges of the bed topography result. The uncertainty of this source of error can be assigned to $\pm 5 \mathrm{~m}$ on average. In isolated areas uncertainties of up to $\pm 15 \mathrm{~m}$ can occur due to blurry reflection. Another source of error are uncertainties about the propagation velocity of the electromagnetic wave. The velocity is well known, and therefore the effect on the uncertainty of the ice thickness is negligible small. Further uncertainties are introduced by the projection of the GPR signals on two-dimensional profile sections. The uncertainties associated with this kind of error are spatially highly variable and are difficult to quantify. Hence, this error was not included in the uncertainty analysis. According to these considerations, an overall uncertainty of $\pm 5 \mathrm{~m}$ was determined for the GPR measurements.

In order to verify the accuracy of the GPR profiles, a comparison between helicopter- and ground-based GPR measurements was performed. The helicopter-based GPR profiles were arranged in a manner allowing a comparison to ground-based measurements. As shown by Fig. 4 the groundbased agree well with helicopter-based GPR measurements. Remaining differences in the ice thickness are mainly due to slight deviations in the projections of the GPR profiles. 


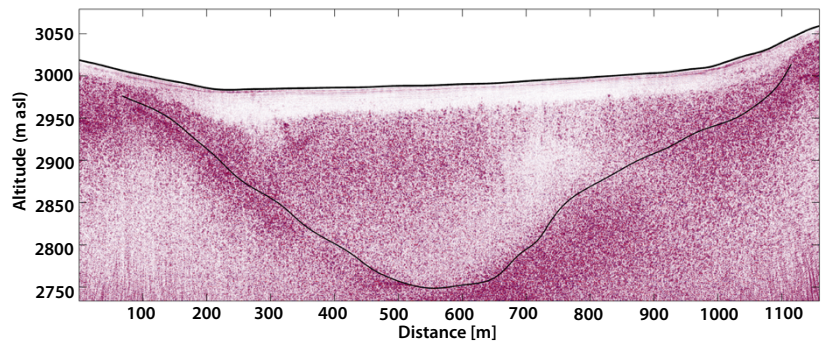

Fig. 3. Processed GPR section across Glacier d'Otemma. Its position is indicated in Fig. 2.

Table 2. Availability of different data sets used for this study: mass balance measurements (MB), DEMs, and the length of GPR profiles. Numbers in brackets indicate the fraction of ground-based GPR profiles from the total length of helicopter- and ground-based GPR profiles for each glacier.

\begin{tabular}{llll}
\hline & MB & DEMs & GPR \\
\hline Corbassière & $1996-2009$ & $\begin{array}{l}1934,1985,1997, \\
\text { 2003, 2009 }\end{array}$ & $34(9) \mathrm{km}$ \\
Giétro & $1966-2009$ & $\begin{array}{l}1934,1983,1998, \\
\text { 2003, 2009 }\end{array}$ & $17(6) \mathrm{km}$ \\
Brenay & - & $1934,1983,2009$ & $8 \mathrm{~km}$ \\
Otemma & - & $1934,1983,2009$ & $15 \mathrm{~km}$ \\
M. Durand & - & $1934,1983,2009$ & $8 \mathrm{~km}$ \\
small gl. & - & $1934,1983,2009$ & - \\
\hline
\end{tabular}

\subsection{Ice-thickness estimation}

Since the GPR profiles covered only a relatively small portion of the glacierized area, an extrapolation procedure was required for obtaining estimates over the entire area of interest. The literature describes different ice-thickness estimation approaches of various complexity (e.g. Farinotti et al., 2009b; Fischer, 2009; Paul and Linsbauer, 2012). All of them combine ice flow mechanics with the information about the surface topography for estimating the depth of the glacier bed.

In this study we applied the ice-thickness estimation method (ITEM) of Farinotti et al. (2009b). ITEM derives the ice-thickness distribution by calculating the ice flow and ensuring mass continuity. Two gradients for the so-called apparent mass balance (i.e. the difference between the actual mass balance and the rate of ice-thickness change), one for the ablation and one for the accumulation zone, have to be assumed. The ice thickness is derived from inverting Glen's flow law (Glen, 1955). A correction factor $c$ accounts for the valley shape, basal sliding and uncertainties in the chosen flow parameters. This factor has to be calibrated by icethickness measurements in order to maximize agreement between GPR measurements and calculated bedrock or has to be estimated from other glaciers.
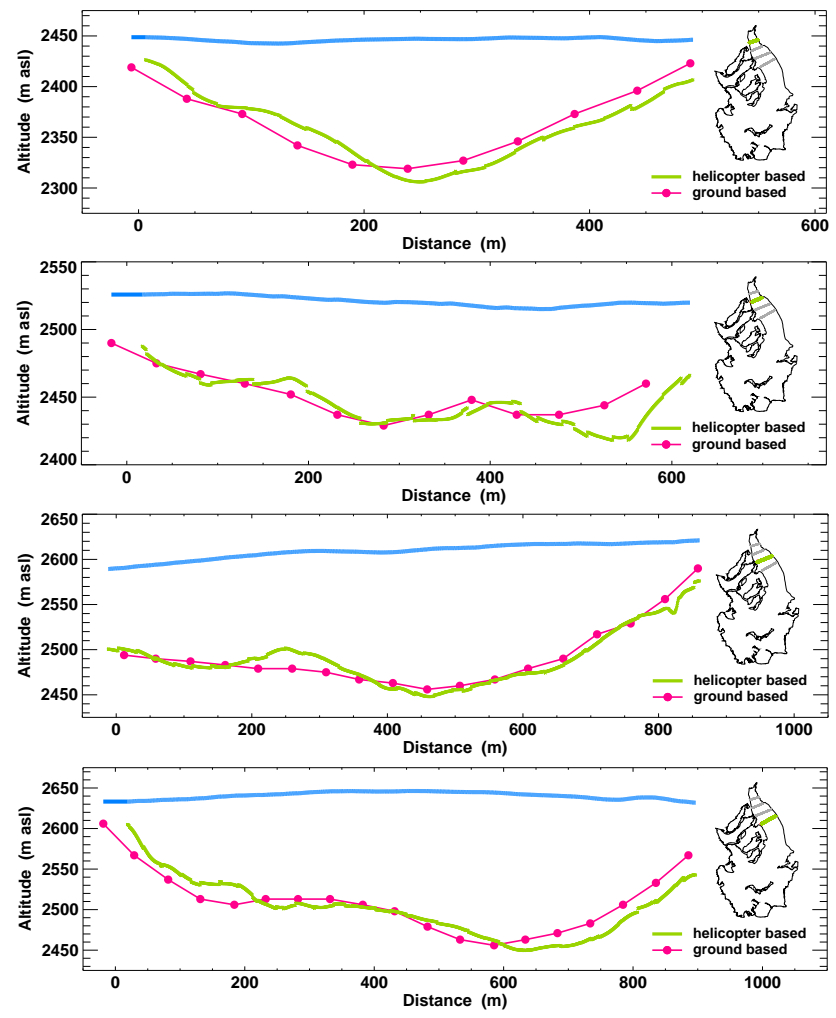

Fig. 4. Comparison of ground-based and helicopter-based GPR profiles. Four GPR profiles of the lower part of Glacier de Corbassière were selected.

We have used our GPR measurements to identify suitable correction factors for each profile. In between the profiles, the correction factors were linearly interpolated. On glaciers, where no GPR data were available, a mean correction factor was used. Gradients of the apparent mass balance were derived by the results of the mass balance model and the observed ice-thickness changes (Table 3).

By interpolation of the GPR profiles, uncertainties are introduced in the ice volume estimation. In order to determine the magnitude of this kind of error, the ice-thickness estimation model was run multiple times for a different number of GPR profiles. By each model run a GPR profile was added to the set of ice-thickness measurements leading to a continuous increase in the accuracy of the ice volume estimation. By including the last profiles to the interpolation, the ice volume uncertainty approached to a level of about $1 \%$. Hence, the uncertainty introduced by the interpolation method is small for glaciers with a comprehensive set of ice-thickness measurements. The uncertainty of the ice volume calculation of glaciers without ice-thickness measurements was assessed taking the performance of the uncalibrated ITEM into account. Uncertainties of the ice volume calculation are shown in Table 3. 
Table 3. Area, maximal $\left(H_{\mathrm{max}}\right)$ and mean $\left(H_{\mathrm{avg}}\right)$ ice thickness, ice volume of (1) $\left(V_{(1)}\right)$ and standard deviation, ice volume of $(5)\left(V_{(5)}\right)$, the relative ice volume difference between $V_{(1)}$ and $V_{(5)}\left(V_{(5: 1)}\right)$, and the calibrated apparent mass balance gradients for the ablation $\left(\mathrm{d} \tilde{b} / \mathrm{d} z_{\text {abl }}\right)$ and accumulation zone $\left(\mathrm{d} \tilde{b} / \mathrm{d} z_{\text {acc }}\right)$ of the Mauvoisin region.

\begin{tabular}{lrrrrrrrr}
\hline Glacier & $\begin{array}{r}\text { Area } \\
{\left[\mathrm{km}^{2}\right]}\end{array}$ & $\begin{array}{r}H_{\text {max }} \\
{[\mathrm{m}]}\end{array}$ & $\begin{array}{r}H_{\mathrm{avg}} \\
{[\mathrm{m}]}\end{array}$ & $\begin{array}{c}V_{(1)} \\
{\left[\mathrm{km}^{3}\right]}\end{array}$ & $\begin{array}{r}V_{(5)} \\
{\left[\mathrm{km}^{3}\right]}\end{array}$ & $\begin{array}{r}V_{(5: 1)} \\
{[\%]}\end{array}$ & $\begin{array}{r}\mathrm{d} \tilde{b} / \mathrm{d} z_{\mathrm{abl}} \\
{[\mathrm{m} / 100 \mathrm{~m}]}\end{array}$ & $\begin{array}{r}\mathrm{d} \tilde{b} / \mathrm{d} z_{\mathrm{acc}} \\
{[\mathrm{m} / 100 \mathrm{~m}]}\end{array}$ \\
\hline Corbassière & 18.3 & 238 & 76 & $1.38 \pm 0.09$ & 1.96 & +42 & 0.55 & 0.14 \\
Otemma & 15.7 & 291 & 67 & $1.05 \pm 0.08$ & 1.42 & +35 & 0.68 & 0.27 \\
Brenay & 9.0 & 212 & 43 & $0.38 \pm 0.04$ & 0.61 & +61 & 0.66 & 0.38 \\
Mont Durand & 7.0 & 144 & 43 & $0.30 \pm 0.03$ & 0.54 & +80 & 0.59 & 0.65 \\
Giétro & 5.5 & 230 & 82 & $0.45 \pm 0.03$ & 0.42 & -7 & 0.81 & 0.70 \\
small glaciers & 7.3 & 83 & 19 & $0.13 \pm 0.03$ & 0.08 & -38 & 0.66 & 0.43 \\
\hline Mauvoisin & 62.8 & 291 & 59 & $3.69 \pm 0.31$ & 5.03 & +36 & 0.66 & 0.43 \\
\hline
\end{tabular}

\subsection{Results}

Based on all available ice-thickness measurements, a total ice volume of $3.69 \pm 0.31 \mathrm{~km}^{3}$ was determined for the Mauvoisin region for the year 2009 (Table 3). Glacier de Corbassière is the largest glacier in the area with an ice volume of $1.38 \pm 0.09 \mathrm{~km}^{3}$. Glacier d'Otemma shows a slightly smaller ice volume of $1.05 \pm 0.08 \mathrm{~km}^{3}$. The three other larger glaciers, Glacier du Brenay, Glacier du Mont Durand, and Glacier du Giétro, have clearly lower ice volumes ranging between $0.30 \pm 0.03$ and $0.45 \pm 0.03 \mathrm{~km}^{3}$. All smaller glaciers together account for $0.13 \pm 0.03 \mathrm{~km}^{3}$ corresponding to approximately $4 \%$ of the total ice volume. The largest ice thickness $(291 \mathrm{~m})$ was found on Glacier d'Otemma (Table 3, Fig. 2). The maximum ice thickness of Glacier de Corbassière is $238 \mathrm{~m}$. Glacier du Brenay and Glacier du Giétro have maximal ice thicknesses of around $220 \mathrm{~m}$. In comparison, Glacier du Mont Durand shows a lower maximal ice thickness of $144 \mathrm{~m}$.

\section{Glacier evolution and runoff modelling}

\subsection{Glacio-hydrological model}

For glacier and runoff projections, the glacio-hydrological model GERM was applied (Huss et al., 2008b; Farinotti et al., 2012). The model is fully distributed and consists of five different modules dealing with accumulation and ablation processes, glacier evolution, evaporation and runoff routing. The model was run on a daily basis for the time period 1900 to 2100 with a spatial resolution of $50 \mathrm{~m}$ and $25 \mathrm{~m}$ for the Mauvoisin and the Corbassière/Petit Combin catchment, respectively. Model and applications to alpine catchments are described by Huss et al. (2008b) and Farinotti et al. (2012) in more detail.

The mass balance model is based on a temperature-index melt model according to the approach by Hock (1999). It calculates the melt on a linear relationship between ablation and air temperature and includes the effect of potential solar radiation, thus accounting for the variability in slope, aspect and topographic shading. The local melt rate $M$ is calculated in daily resolution by

$M=\left\{\begin{array}{cll}\left(F_{M}+r_{\text {ice/snow }} I\right) T & : & T>0{ }^{\circ} \mathrm{C} \\ 0 & : & T \leq 0{ }^{\circ} \mathrm{C}\end{array}\right.$

where $F_{\mathrm{M}}$ is the melt factor, $r_{\text {ice/snow }}$ the radiation factors for ice and snow, respectively, $I$ the potential solar radiation, and $T$ the mean daily air temperature. Below $0^{\circ} \mathrm{C}$ no melting occurs. The accumulation model interpolates the amount of precipitation at the reference location to any location in the catchment on the basis of a calibrated precipitation gradient $\mathrm{d} P / \mathrm{d} z$ and a precipitation correction factor $c_{\text {prec }}$. Linear transition within a temperature range of $0.5-2.5^{\circ} \mathrm{C}$ is used in order to distinguish between snow and rainfall. Further, a spatially dependent snow distribution factor, which is constant over time, is implemented and accounts for snow transport processes through wind or gravity (e.g. avalanches).

Glacier surface is updated according to the so-called $d h$ parameterisation (Huss et al., 2010). This method relies on the fact that ice thickness changes across a longitudinal profile of a glacier show a typical pattern which is approximately constant over time (Jóhannesson et al., 1989). In the parameterisation, the annual ice volume change computed by the mass balance model is distributed over the glacier surface according to a predefined pattern. Thereby, the pattern is obtained analysing historic glacier changes in the region of interest.

The runoff routing model consists of three different reservoirs: an interception, a fast and a slow one. In first instance, the water (sum of liquid precipitation and melt) infiltrates in the interception reservoir until it is filled. Afterwards the water is distributed in the fast and the slow reservoir. The filling rate depends thereby on the actual filling level of the slow reservoir. The fast reservoir indicates the near-surface, fast responding runoff, the slow one the runoff from deeper layers retaining water over a longer period. In case of a snow cover, there is a fourth snow reservoir. Part of the outflow from the snow reservoir infiltrates in the soil; the other one contributes 
directly to runoff. The total runoff is computed by adding the discharge of the slow, the fast and the direct runoff from the snow reservoir. The water loss of the interception reservoir is only controlled by evaporation. The individual reservoirs act as so-called linear reservoirs where the runoff volume is proportional to the actual filling level of the reservoir. The model distinguishes between five different surface types: ice, snow, rock, low (meadow) and high vegetation (forest). The size of the reservoirs and the corresponding retention constant are dependent on the surface type. For further details on the GERM model, refer to Farinotti et al. (2012).

\subsubsection{Model forcing}

The model is forced with continuous temperature and precipitation time series (1900-2100) with daily evolution. In order to reconstruct the past climate conditions (1900-2009) in the Mauvoisin area, regional temperature and precipitation data from weather stations in the vicinity of the study site are taken into account. Monthly temperature values between 1900 and 2009 were obtained by inverse-distance weighting of the homogenized climate time series of 12 different weather stations maintained by MeteoSwiss (Begert et al., 2005). In order to get temperature time series with daily resolution, daily fluctuations of the weather station in Sion were superimposed on the monthly values. Temperature lapse rates were computed by using data of weather stations closer than $50 \mathrm{~km}$ to the study area (Fig. 1). The homogenized temperature time series were shifted to the mean altitude of the investigated catchment by using the temperature lapse rate. For precipitation, the time series of the weather station of Bourg-St-Pierre were chosen due to the vicinity to the study site and the long record reaching back to 1900 . These daily precipitation time series were scaled in order to match the monthly precipitation values given by the PRISM data set (Schwarb et al., 2001). The data set provides mean monthly precipitation sums for the Swiss Alps on a grid with $2 \mathrm{~km}$ resolution and the period 1971-1990. Precipitation lapse rate is determined during the calibration procedure by using the mass balance data. Temperature and precipitation lapse rate were kept constant over time. For further information about the generation of the climate time series of the past, see Huss et al. (2008a).

Future climate time series (2010-2100) of the Mauvoisin region are based on scenarios developed in the framework of the European ENSEMBLES project (van der Linden and Mitchell, 2009). Regional climate scenarios of 10 different model chains (combination between general circulation models and regional climate models) based on emission scenario SRES A1B (IPCC, 2000) were used. The data were obtained from the Center for Climate Systems Modeling $(\mathrm{C} 2 \mathrm{SM})$ providing daily temperature and precipitation changes for two periods in the future (2021-2050; 20702099) in comparison to a period in the past (1980-2009) (CH2011, 2011; Bosshard et al., 2011).
In order to meet the model requirements of continuous climate time series, the changes in temperature and precipitation between the different periods are assigned to the middle of each period and are linearly interpolated in between. An interannual variability is introduced by superimposing daily fluctuations of the past on the interpolated time series. We followed the approach of Farinotti et al. (2012) and generated 10 different meteorological time series for each of the ten considered model chains. This results in 100 different time series of daily temperature and precipitation by which the model can be forced and allows to estimate a possible bandwidth for the climate evolution.

According to the climate projections provided by C2SM, the temperature in the Mauvoisin region (weather station at $1840 \mathrm{~m}$ a.s.l.) will increase by about $1.2 \pm 0.44^{\circ} \mathrm{C}$ on average until $2021-2050$ and by about $3.4 \pm 0.63^{\circ} \mathrm{C}$ until $2070-2099$ compared to the reference period. Mean precipitation will increase by about $1.4 \pm 2.4 \%$ until the first period, but decreases by about $-2.8 \pm 3.8 \%$ until the second period. These average changes in temperature and precipitation are not uniformly distributed over the year. Temperature is projected to increase most during summer and precipitation most in spring and autumn.

\subsubsection{Calibration}

The calibration of the model parameters was performed by an automated multi-layer iterative procedure as described in Huss et al. (2008b) and Farinotti et al. (2012). In addition to hydrometric data, glacier volume changes and direct mass balance measurements were incorporated in the calibration procedure, which strongly reduce the uncertainties of the model parameters (Jost et al., 2012; Stahl et al., 2008). Optimum calibration is essential in order to ensure reliable glacier and runoff projections. Inappropriate parameter estimation or changes in parameter values in the future may lead to deviations from the predicted glacier and runoff evolution (see Discussion).

In a first step, the parameters of the melt and the accumulation module $\left(F_{\mathrm{M}}, r_{\text {ice/snow }}, c_{\text {prec }}, \mathrm{d} P / \mathrm{d} z\right)$ were calibrated by means of observed ice volume changes and mass balance measurements (Table 4). Melt and radiation factors were adjusted according to ice volume changes, precipitation gradient and precipitation correction factor according to mass balance measurements. The temperature gradient $\mathrm{d} T / \mathrm{d} z$ was previously determined by means of climate data from weather stations near the study site as described in Sect. 4.1.1. In a second step, the parameters of the runoff routing model were iteratively adjusted in order to ensure maximal agreement between observed and modelled runoff (Table 4). For validation the Nash-Sutcliffe criterion was calculated for daily, monthly, and annual runoff volumes (Nash and Sutcliffe, 1970). The model parameters were cross validated by calibrating the parameters for the period 1934-1983 and validating them for the period 
Table 4. Overview of the calibrated parameter sets of the melt, accumulation and runoff model shown for the two subcatchments Mauvoisin (Mauv) and Corbassière/Petit Combin (Corb). The retention constants for the fast reservoir and the maximal capacity of the slow and the fast reservoir depend on the surface type (ice, snow, rock, low and high vegetation, open water).

\begin{tabular}{lllrr}
\hline Parameter & Explanation & Unit & Mauv & Corb \\
\hline Melt model: & & & & \\
$F_{\mathrm{M}}$ & Melt factor & {$\left[10^{-4} \mathrm{~m} \mathrm{~h}^{-1}{ }^{\circ} \mathrm{C}^{-1}\right]$} & 1.169 & 1.016 \\
$r_{\text {ice }}$ & Radiation factor for ice & {$\left[10^{-6} \mathrm{~m}^{3} \mathrm{~W}^{-1}{ }^{\circ} \mathrm{C}^{-1}\right]$} & 0.780 & 0.677 \\
$r_{\text {snow }}$ & Radiation factor for snow & {$\left[10^{-6} \mathrm{~m}^{3} \mathrm{~W}^{-1}{ }^{\circ} \mathrm{C}^{-1}\right]$} & 0.390 & 0.231 \\
$\mathrm{~d} T / \mathrm{d} z$ & Temperature gradient & {$\left[\mathrm{C} \mathrm{m}^{-1}\right]$} & -0.0053 & -0.0053 \\
\hline Accumulation & model: & & & \\
$\mathrm{d} P / \mathrm{d} z$ & Precipitation lapse rate & {$\left[\% \mathrm{~m}^{-1}\right]$} & 0.15 & 0.05 \\
$C_{\text {prec }}$ & Precipitation correction factor & {$[-]$} & 30.0 & -10.0 \\
\hline Runoff model: & & & & \\
$k_{\text {fast }}$ & Retention constant fast reservoir & {$[\mathrm{d}]$} & $2-30$ & $2-30$ \\
$k_{\text {slow }}$ & Retention constant slow reservoir & {$[\mathrm{d}]$} & 50 & 50 \\
$k_{\text {snow }}$ & Retention constant snow reservoir & {$[\mathrm{d}]$} & 5 & 5 \\
$V_{\text {slow,max }}$ & Max. capacity slow reservoir & {$[\mathrm{mm}]$} & $200-5000$ & $200-5000$ \\
$V_{\text {int,max }}$ & Max. capacity interception reservoir & {$[\mathrm{mm}]$} & $0-2.5$ & $0-2.5$ \\
\hline
\end{tabular}

1983-2009 and vice versa. The Nash-Sutcliffe criterion of the monthly runoff values is 0.93 and 0.94 for the Mauvoisin and the Corbassière/Petit Combin catchment, respectively, and of the daily runoff values 0.86 and 0.87 , respectively. The bias between the modelled and the measured annual runoff is on average +1.2 mio m$^{3} \mathrm{a}^{-1}\left(+0.6 \%\right.$ or $\left.+10.5 \mathrm{~mm} \mathrm{a}^{-1}\right)$ and $-0.5 \mathrm{mio} \mathrm{m}^{3} \mathrm{a}^{-1}\left(-0.9 \%\right.$ or $\left.-14.5 \mathrm{~mm} \mathrm{a}^{-1}\right)$ for the Mauvoisin and the Corbassière/Petit Combin catchment, respectively. The parameters of the evaporation module are adopted from Huss et al. (2008b) and Farinotti et al. (2012).

\subsection{Results}

\subsubsection{Glacier evolution}

Since the beginning of the 20th century, the glaciers in the Mauvoisin region have been in retreat. Between 1900 and 2009 the initial ice volume has decreased by $43 \%$, from $6.49 \mathrm{~km}^{3}$ to $3.69 \mathrm{~km}^{3}$. Almost half of this ice volume loss occurred during the past $30 \mathrm{yr}$. Hence, the retreat rate has nearly doubled since the beginning of the 1980s (Fig. 5). Similar mass balance rates could be also observed between 1943 and 1954. Only a short period of mass gain was observed between 1978 and 1983, when the ice volume increased by about 192 mio $^{3}$ corresponding to an increase of $3.6 \%$ in total ice mass.

According to the applied model, all glaciers in the Mauvoisin region will severely retreat in the future independent of their size. By the end of the 21st century, the entire area will be nearly ice-free. Only some ice patches above $3500 \mathrm{~m}$ a.s.l., with a total ice volume of $0.11 \mathrm{~km}^{3}$ $\left(0.08 \leftrightarrow 0.24 \mathrm{~km}^{3}\right)$, are expected to remain. Small glaciers will vanish completely.
The amount of retreat of the glaciers in the Mauvoisin region is mainly controlled by the elevation of their accumulation area (Fig. 6). Small glaciers or parts of them below $3000 \mathrm{~m}$ a.s.l. are expected to disappear by 2020 as in case of Glacier de Fenêtre, Glacier de la Tsessette and, to some extent, also Glacier de Crête Sèche. Small glaciers situated at higher altitudes, such as Glacier de Tournelon Blanc, will persist longer.

Model results revealed that larger glaciers, especially those with large ice volumes and high-altitude accumulation areas, will retreat considerably more slowly than the smaller ones. Within the next few decades, the larger glaciers will be affected mainly by thinning. Only at a later stage (after 2050), the glaciers are expected to show significant areal wastage. Glacier d'Otemma shows a particularly fast retreat in contrast to the other larger glaciers in the area as indicated by our model. Already around 2070 Glacier d'Otemma will have almost entirely vanished except of some tiny ice patches in the uppermost part. The reason for the rapid retreat of the Glacier d'Otemma despite the large initial ice volume can be associated with its main basin restricted to altitudes below 3100 m a.s.l. In comparison, in 2070 Glacier de Corbassière will cover almost half of its initial area because of considerable ice masses situated at altitudes above $4000 \mathrm{~m}$ a.s.l.

\subsubsection{Hydrology}

According to our reconstruction, the annual runoff increased from 216 to $265 \mathrm{mio} \mathrm{m}^{3} \mathrm{a}^{-1}(23 \%)$ between 1900 and 2009, but this rise was not constant over time. In two successive periods from 1910 to 1945 and from 1975 to 1995, the annual runoff volume has increased by about 45 mio m$^{3} \mathrm{a}^{-1}(\sim 20 \%)$ and has reached maximal runoff of 


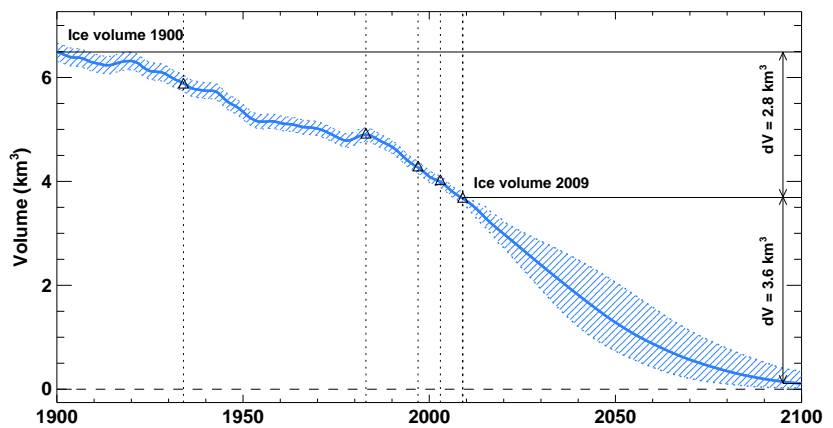

Fig. 5. Ice volume evolution in the Mauvoisin region between 1900 and 2100 . The hatched zone represents the $95 \%$ confidence interval for the past given by the ice volume uncertainty and for the future given by the 100 different model runs. Black triangles and corresponding dotted lines show years in which a DEM is available.

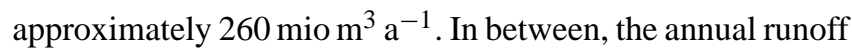

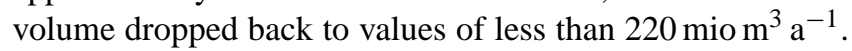
These fluctuations can be correlated with the glacier evolution as well as with changes in temperature and precipitation (Fig. 7). In the next two decades, annual runoff is projected to increase to approximately $275 \mathrm{mio} \mathrm{m}^{3} \mathrm{a}^{-1}(+4 \%)$. Afterwards, a continuous decline is expected until the end of the 21 st century. Compared to the maximal runoff volume of $275 \mathrm{mio} \mathrm{m}^{3} \mathrm{a}^{-1}$, the annual runoff will drop about $25 \%$ to $207 \mathrm{mio} \mathrm{m}^{3} \mathrm{a}^{-1}$ until 2100 . In comparison to a previous study addressing nine selected catchments in the Swiss Alps (Farinotti et al., 2012), in future runoff evolution in the Mauvoisin catchment shows a similar evolution as other strongly glacierized catchments.

The changing climate and the associated glacier wastage will not only affect the amount of annual runoff, but also the individual runoff components, leading to significant changes in the runoff regime. At present, the runoff regime is dominated by ice- and snowmelt and shows a peak discharge in the months July and August (Fig. 8). Modelled runoff projections indicate that, in the future, the mean daily runoff in summer will strongly diminish, whereas during winter daily runoff will slightly enhance due to higher air temperatures. Currently, a maximum mean daily runoff of $28 \mathrm{~m}^{3} \mathrm{~s}^{-1}$ is attained at the end of July, which will decrease to $18 \mathrm{~m}^{3} \mathrm{~s}^{-1}$ until the year 2100. Beside the reduction of daily runoff, also a shift of peak runoff is expected. According to the model, maximal runoff values will occur 1.5 months earlier at the end of the 21 st century compared to the reference period. This shift of the peak discharge from end of July to mid-June results from the decrease of the runoff volumes in the months July to September by about $44 \%$ compared to the reference period. Furthermore, the runoff projections indicate that daily runoff increases slightly earlier in spring compared to the present situation due to the earlier onset of the snowmelt season. The time offset between the beginning of the melt season in the reference period and in 2100 is around three weeks. Similar changes in the runoff regimes of high-alpine

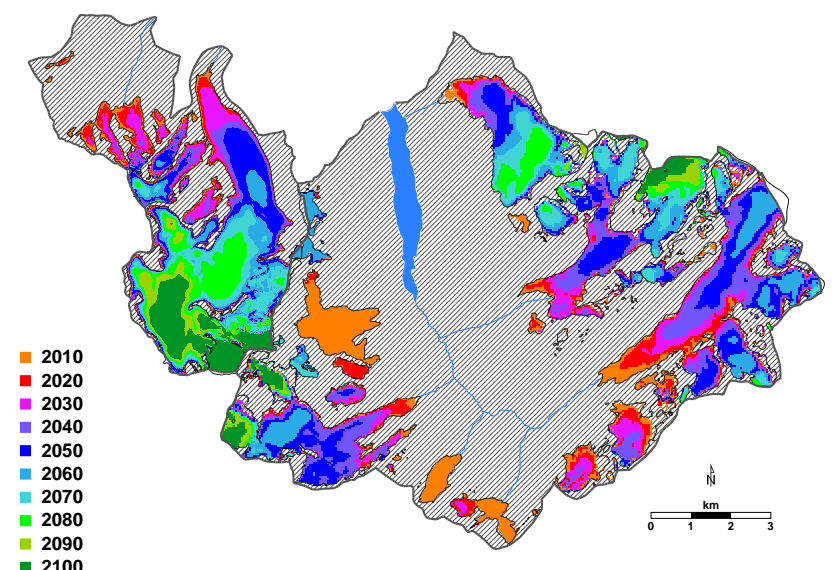

Fig. 6. Projected glacier retreat in the Mauvoisin region until the end of the 21 st century. Glacier area is shown in 10-yr steps. Hatched zones framed by grey thick lines represent the outlines of the two subcatchments Mauvoisin and Corbassière/Petit Combin.

basins in the future have been reported by other studies (Horton et al., 2006; Uhlmann et al., 2012).

The reason for these changes in the runoff regime becomes evident by considering the evolution of the different sources of water input to the runoff model with progressing climate change (Fig. 9). The model employed distinguishes between liquid precipitation, snowmelt, and ice melt. Firn is counted to ice melt. Between the sum of the three water input components (Fig. 9) and the runoff regime (Fig. 8) is a slight difference originating from runoff routing. During the reference period (1980-2009), snowmelt is the main component and accounts for $60 \%$ of the water input. At present, snow runoff contribution starts to increase mid-May and reaches a maximum at the beginning of July. The ice melt increases later in the season (at the beginning of June), and its maximum occurs around the end of July. Model projections show that maximum snowmelt is shifted to the beginning of June and that the ice melt is reduced and its maximum shifted to mid-August by the end of the 21 st century. Hence, the shift of the snowmelt peak and the reduction of the ice melt lead to reduced runoff volumes in July and August as shown by the runoff regime evolution.

According to our model, ice melt will decrease about $74 \%$ between 2010 and 2100 and will contribute only by $2 \%$ to total runoff in the year 2100 . The remaining runoff will originate in equal parts from snowmelt $(48 \%)$ and liquid precipitation $(50 \%)$. Snow melt will experience a less pronounced decrease than ice melt. From 2010 to 2100 snowmelt reduces about $11 \%$. The reduction of snowmelt is caused by less solid precipitation due to the expected temperature rise and generally decreased precipitation amounts. In fact, total precipitation will reduce about $6 \%$ until 2100 compared to the reference period (1980-2009). The results of the runoff analysis are summarized in Table 5 . 


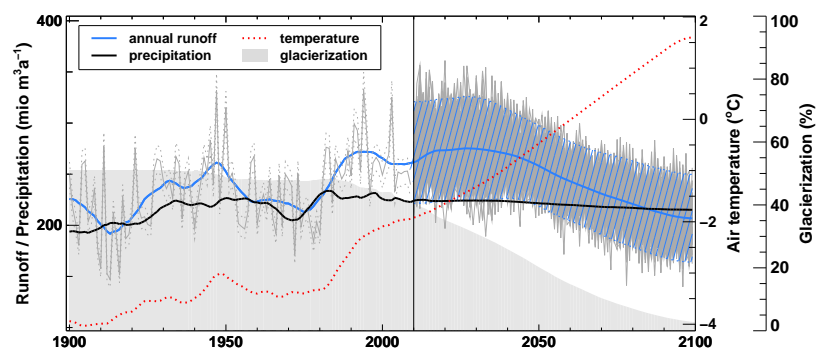

Fig. 7. Evolution of annual runoff, precipitation, air temperature and glacierization in the Mauvoisin catchment. Bold lines represent running means, the thin grey line the effective evolution of the annual runoff. The blue hatched zone shows the $95 \%$ confidence interval of the annual runoff determined from multiple model runs. The grey dotted lines indicate the $95 \%$ confidence interval of the effective annual runoff evolution in the past based on the bias between modelled and measured annual runoff. The grey shaded area refers to the percentage of the ice covered area in the catchment.

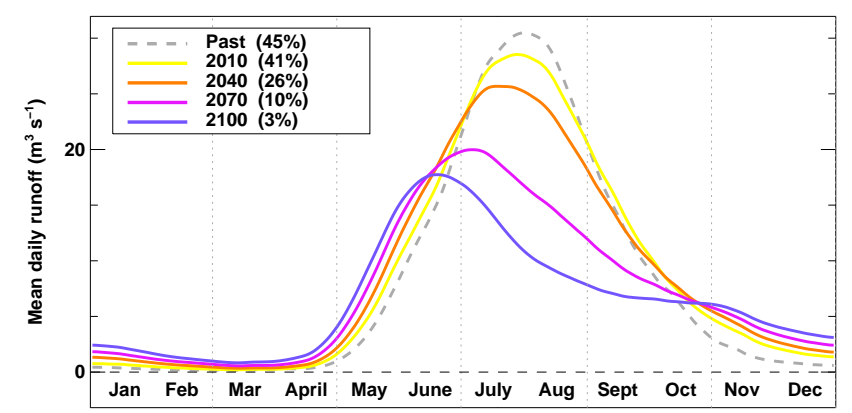

Fig. 8. Evolution of the runoff regime in the Mauvoisin region for the reference period and four time snapshots in the future averaged over \pm 5 yr. Numbers in brackets refer to the percentage of glacier cover.

\section{Ice volume sensitivity analysis}

Extensive helicopter-borne GPR measurements allowed the ice-thickness distribution in the Mauvoisin area to be determined accurately. If such data sets are not available, simplified models need to be employed. By means of a sensitivity analysis, we have quantified the influence of the initial icethickness distribution on glacier and runoff projections.

For that purpose, we considered five different icethickness distributions (Fig. 10).

1. Approach as described in Sect. 3.2., case (1) refers to the reference ice-thickness distribution based on the measurements.

2. Ice-thickness distribution has the same pattern as (1) but scaled by $+20 \%$. This case shows the influence of overestimated total ice volumes on runoff projections.

3. Ice-thickness distribution has the same pattern as (1) scaled by $-20 \%$. Case (3) emphasizes the impact of underestimation of the total ice volume on the runoff evolution.
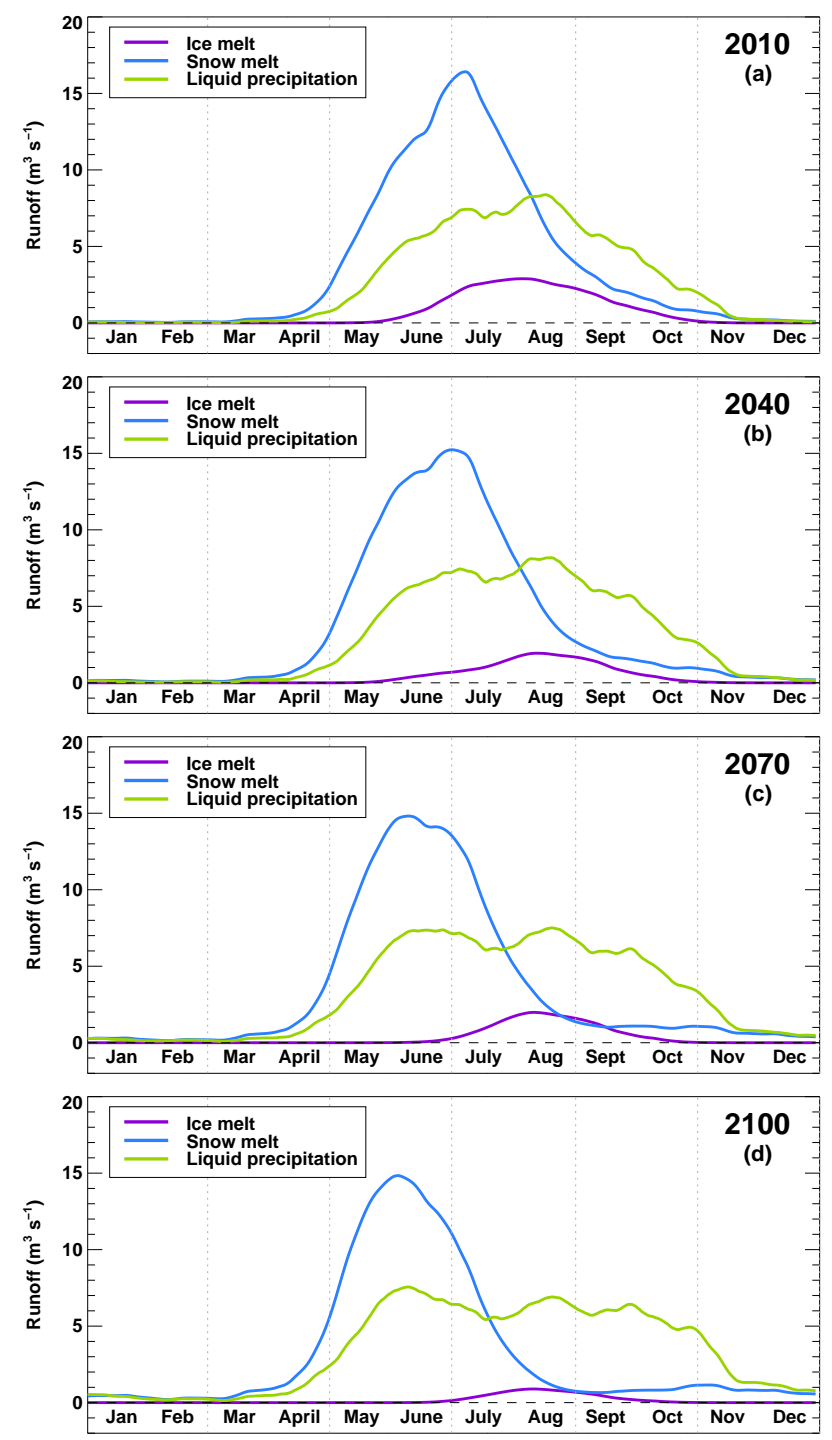

Fig. 9. Evolution of the three components of the water input to the runoff routing model for the years 2010 (a), 2040 (b), 2070 (c), and 2100 (d). The values are averaged over $\pm 5 \mathrm{yr}$.

4. Ice-thickness distribution is uniform with a mean ice thickness calculated by the ice volume based on (1) for each glacier. This distribution is the most simple case and is used in most macro-scale hydrological models where ice volume is crudely processed (Fig. 10c).

5. Ice-thickness distribution is calculated by the ITEM assuming a correction factor $c$ of 0.53 as used in the study by Farinotti et al. (2009a) for unmeasured glaciers. Apparent mass balance gradients are set to $0.9 \times 10^{-2} \mathrm{a}^{-1}$ for the ablation zone and to $0.5 \times 10^{-2} \mathrm{a}^{-1}$ for the accumulation zone. This method provides a spatial distribution pattern based on the glacier surface topography. Case (5) shows the performance of ITEM if no icethickness measurements are available (Fig. 10b). 

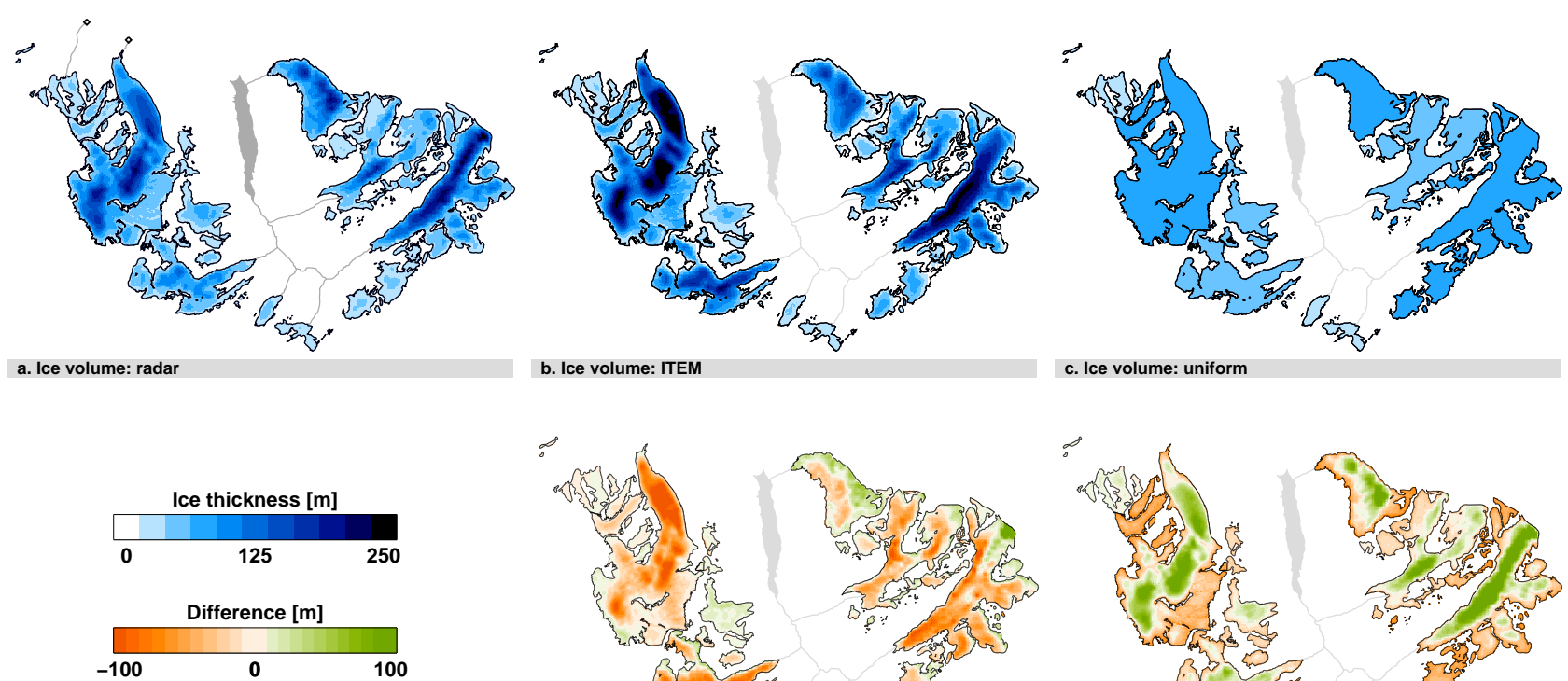

b. Ice volume: ITEM
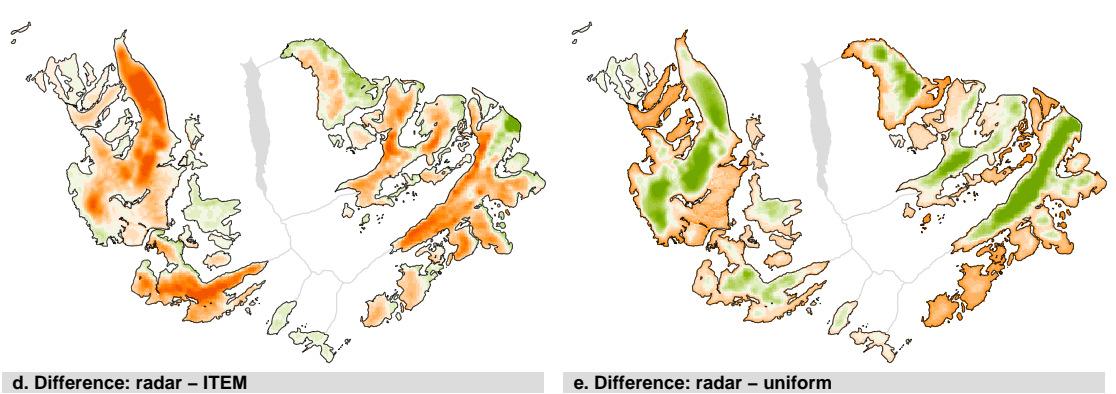

Fig. 10. The different ice-thickness distributions: (a) the GPR-based ice volume distribution, (b) the ice-thickness distribution derived by ITEM, and (c) the uniform ice-thickness distribution. (d) and (e) refer to the ice-thickness difference to the reference distribution determined by measurements.

Table 5. Summary of the main results of this study. The evolution of the ice volume, the glacierized area, the annual runoff and the different components of water input to the runoff routing model (ice melt, snowmelt, and liquid precipitation) is shown for the period 1920-2100 in 30 -yr steps. Values are averaged over $\pm 5 \mathrm{yr}$.

\begin{tabular}{llrrrrrrr}
\hline Quantity & Unit & 1920 & 1950 & 1980 & 2010 & 2040 & 2070 & 2100 \\
\hline Ice volume & $\mathrm{km}^{3}$ & 6.2 & 5.3 & 4.3 & 2.4 & 1.8 & 0.6 & 0.1 \\
Glacier area & $\mathrm{km}^{2}$ & 75.9 & 72.7 & 71.7 & 61.6 & 38.6 & 15.5 & 4.2 \\
\hline Annual runoff & $10^{6} \mathrm{~m}^{3} \mathrm{a}^{-1}$ & 207 & 258 & 223 & 260 & 270 & 231 & 206 \\
Ice melt & $10^{6} \mathrm{~m}^{3} \mathrm{a}^{-1}$ & 19 & 15 & 6 & 19 & 13 & 11 & 5 \\
Snow melt & $10^{6} \mathrm{~m}^{3} \mathrm{a}^{-1}$ & 103 & 126 & 121 & 119 & 118 & 112 & 105 \\
Liquid precipitation & $10^{6} \mathrm{~m}^{3} \mathrm{a}^{-1}$ & 51 & 66 & 61 & 85 & 96 & 103 & 109 \\
\hline
\end{tabular}

When assuming a constant correction factor $c=0.53$ (5), ITEM overestimates the total ice volume of the Mauvoisin region by about $36 \%$ (Table 3). Especially for Glacier du Brenay and Glacier du Mont Durand, the ice volume is overestimated by 61 and $80 \%$, respectively. Glacier du Giétro shows in case of $c=0.53$ an exceptional small deviation of only $-7 \%$. Glacier de Corbassière and Glacier d'Otemma show mainly in the lower area large ice-thickness deviations between the GPR- and the ITEM-based bed topography of up to $130 \mathrm{~m}$ (Figs. 10 and 11). Glacier du Brenay and Glacier du Mont Durand show deviations in the ice thickness of the same order, but the largest deviations are located more in the center than on the lower part of the glacier.

\subsection{Impact of initial ice volume distribution on runoff}

The different ice volume distributions significantly affect the runoff projections. In case of the GPR-derived ice volume, (1) annual runoff will slightly increase (about $4 \%$ ) from 2010 until about 2030 to a maximal annual runoff volume of $275 \mathrm{mio} \mathrm{m}^{3} \mathrm{a}^{-1}$. Afterwards, the runoff volume starts to decrease gradually until 2100 (Fig. 12). Overestimation of the total ice volume of about $20 \%$ (2) results in a pronounced increase of the annual runoff over a prolongated period of time compared to GPR-derived runoff. Peak discharge will occur around $10 \mathrm{yr}$ later with a volume of $279 \mathrm{mio} \mathrm{m}^{3} \mathrm{a}^{-1}$ $(+1 \%)$ compared to (1). Underestimation of the total ice volume (3) leads in the case of the Mauvoisin region to changes in the trend of the runoff evolution in the next decades. Instead of a further runoff increase, annual runoff continuously 


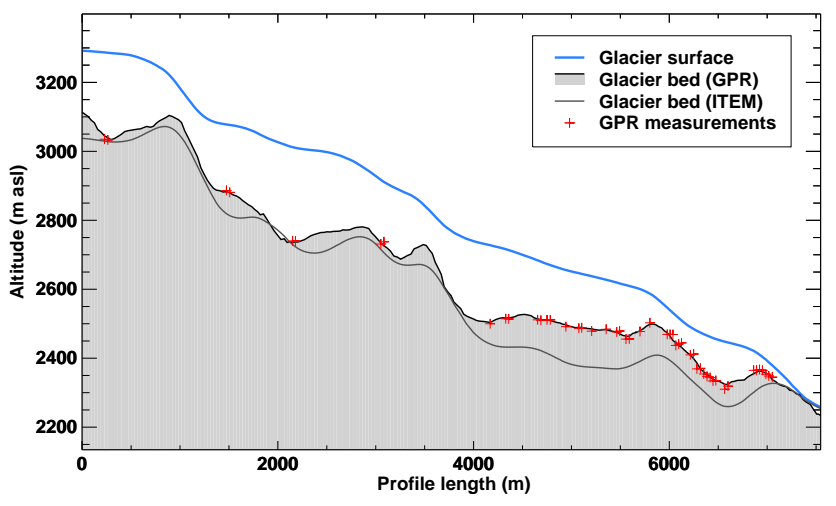

Fig. 11. Longitudinal profile along the central flow line of Glacier de Corbassière (see Fig. 1). The thin black line refers to the glacier bed derived from the GPR measurements, the thin grey line to the bed computed by the ITEM and the blue line to the glacier surface. The red crosses mark the GPR-based ice-thickness measurements.

decreases until the end of the 21 st century with general lower runoff volumes compared to GPR-derived results. Neglecting a spatial ice volume distribution by assuming uniform icethickness distribution (4) leads to an overestimation of the runoff in the next two decades due to too large ice masses in low altitude. Maximal annual runoff will occur around 2020 with a peak discharge of $283 \mathrm{mio} \mathrm{m}^{3} \mathrm{a}^{-1}$ (3\%). In a later stage, the runoff of the uniform ice volume distribution aligns to the GPR-derived runoff curve. The application of ITEM with the uncalibrated and fixed parameter set (5) overestimates the ice volume in the Mauvoisin region about $36 \%$ which results in a similar runoff evolution as in case of the ice volume overestimated by $20 \%$ (2). But, in case (5) the annual runoff shows a sharper increase of $12 \%$ between 2010 and 2040. A maximum peak runoff of $287 \mathrm{mio} \mathrm{m}^{3} \mathrm{a}^{-1}$ is expected in this case.

\section{Discussion}

The ice volume sensitivity study emphasizes the importance of an accurate ice volume determination for glacier and runoff projections. The incorporation of ice-thickness measurements in the ice volume calculation is crucial in order to receive reliable ice volumes and ice-thickness distributions. Inaccurate estimations of the total ice volume will cause deviations from the predicted general runoff trend. In case of the Mauvoisin region, it could be shown that an overestimated ice volume reveals a sharp runoff increase in the the next few decades, whereas estimations supported by measurements show almost no further increase in annual runoff. The ice-thickness distribution affects the runoff evolution as well, but not as pronounced as in case of an overestimated ice volume. A uniform ice volume distribution entails particularly in the next few decades an overestimation of runoff and is therefore less suitable for short- and mid-term projections.

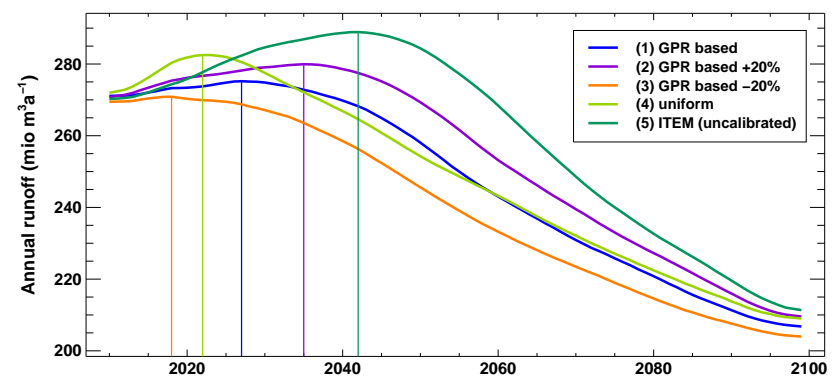

Fig. 12. Runoff projections based on the different initial icethickness distributions. The numbers in brackets refer to the different initial ice volume distributions presented in Section 5.

After major ice volume has melted, it only differs slightly from the GPR-derived runoff evolution. In absence of icethickness measurements, a mean parameter set has to be assumed carrying the potential of over- or underestimation of the true ice volume. In case mass balance measurements are available, mass balance gradients can be adjusted leading to improvements in the ice volume estimation. Due to the high sensitivity of the ice volume estimation on the correction factor (Farinotti et al., 2009b), the use of an appropriate correction factor is of much higher importance compared to the mass balance gradients. Knowledge about the local ice thickness enables the calibration of the correction factor resulting in a significantly increased accuracy of the ice volume estimation. New approaches are required for better assessing correction factors for individual glaciers if no ice-thickness measurements are available. Our results suggest that the incorporation of GPR-based ice-thickness measurements is of high importance in order to provide reliable runoff projections especially for the next $30-40 \mathrm{yr}$ when profound changes are expected.

Despite the high density of ice-thickness measurements and the application of an ice-thickness estimation method, the true bed topography is not fully known. Uncertainties arise due to uncertainties of the ice-thickness measurements and due to the interpolation method. Taking these two sources of error into account, an overall uncertainty of $\pm 8 \%$ was determined for the total ice volume. This uncertainty leads to the same alterations of the runoff projections as shown by the results of the sensitivity analysis for underand overestimated ice volume (20\%), but less pronounced.

A simple approach to compute the glacier evolution is the accumulation area ratio (AAR) method as used by several studies (e.g. Schaefli et al., 2007; Paul et al., 2007). This method updates the glacier surface according to the modelled accumulation area and a fixed accumulation area ratio assuming infinite ice volume. Moreover, no mass conservation is provided. Huss et al. (2008b) showed a poor performance of the AAR method compared to an approach with a transient glacier evolution model and an initial ice volume distribution. According to Huss et al. (2008b), the annual runoff volume 
is up to $30 \%$ underestimated by the AAR approach, which is clearly below the performance of all tested ice volume distributions.

The reliability and usefulness of the glacier evolution and runoff projections are also affected by uncertainties in the future climate evolution. The climate scenarios applied are based on the most recent climate study and incorporate different combinations of regional and general circulation models. However, only emission scenario SRES A1B (IPCC, 2007) was considered. Deviations from the chosen emission scenario might entail a different glacier evolution and consequently changes in the projected future runoff regime.

Uncertainties arise also from the chosen model approach. The prediction of the glacier evolution is determined on the basis of a temperature-index melt model in combination with an accumulation model. Due to the low data requirement of this approach, it is well suited for distributed modelling of entire catchments and available for future climate scenarios. However, temperature-index melt models act just as simplified approaches of the true surface energy balance and react only to changes in the temperature and precipitation field. Other factors, such as variations in incoming or outgoing radiation or changes in the wind field, are not incorporated and may lead to different results. In the 1940s, a rise in the global radiation led to higher melting rates compared with today's climate conditions despite of lower air temperatures (Huss et al., 2009). Such variations of solar radiation are not captured by temperature-index melt models retaining a constant parameter set and might yield discrepancies between projected and real glacier evolution.

Furthermore, uncertainties about the model parameters have the potential to cause deviations from glacier and runoff projections. The study of Farinotti et al. (2012) reveals that runoff projections are particularly sensitive to changes in the temperature gradient and melt parameter values. The study shows that a reduction of the temperature lapse rate by $10 \%$ yields a decrease of the mean annual runoff between 2010 and 2100 of about $25 \%$ and that an increase of the melt parameters of $10 \%$ leads to an increase of the mean annual runoff of 11 to $20 \%$ in the same period. The temperature distribution has a big impact on runoff projections, because it controls the snow and ice melt and additionally also the phase of precipitation. Under- or overestimation of the total ice volumes leads to deviations in the mean glacier melt of the same order. In case of the ITEM-derived glacier bed topography, the total ice volume is overestimated by $36 \%$ leading to a reduction of the mean glacier-induced runoff between 2010 and 2100 of about $31 \%$. This corresponds to a mean annual runoff reduction of about $4 \%$ in the period 2010 to 2100 , which is less than the effect of the temperature gradient and the melt parameters, because the ice volume affects the ice melt component only. But the discrepancy between the two runoff evolutions is higher for individual years, as around 2050, where the annual runoff based on the ITEM-derived ice volume distribution is overestimated by about $10 \%$. For glacierized catchments the incorporation of glacier-specific data for the calibration procedure is crucial in order to reduce the uncertainty of the model parameters and to provide reliable projections (Stahl et al., 2008; Jost et al., 2012). For this reason we are confident that the calibrated parameters are, despite the simple calibration method, appropriate for modelling the glacier and runoff evolution. Further improvements in the parameter estimation might be achieved by applying a more sophisticated optimization algorithm, but uncertainty about the validity and potential variations of the parameters in the future will remain.

Enlargement of the debris-covered area of a glacier might yield attenuation of the glacier retreat in future. Glacier d'Otemma and Glacier du Brenay show already an extended debris cover in the ablation zones. During the last decades, especially small glaciers in the Mauvoisin area have shown a strong increase in debris cover. Similar observations have been reported from other mountain regions (KellererPirklbauer, 2008; Popovnin and Rozova, 2002; Stokes et al., 2009). In contrast, an increase in dust cover reduces the albedo and leads to an intensification of the melt process (Oerlemans et al., 2009). Insufficient understanding of the processes yielding changes in debris or dust cover and lack of data inhibit the implementation of debris cover evolution in melt models (Reid and Brock, 2010).

Moreover, the glacier evolution also involves uncertainties arising from the accumulation model. The spatial distribution of precipitation and the distinction between liquid and solid precipitation are complex. Variable redistribution of snow by wind and avalanches further increases the complexity of the accumulation pattern (Lehning et al., 2008). The applied model includes a simplified snow redistribution approach but assumes constant snow redistribution patterns in time. Further effort is required to increase the accuracy in modelling the snow distribution on glaciers (Dadic et al., 2010).

Projections of the annual runoff volume and the runoff regime were compared to the results of the study by Schaefli et al. (2007) which investigated the influence of the climate change on the hydropower production in the Mauvoisin region by a more simplified approach. Our results show higher annual runoff volumes by the end of the 21 st century compared to Schaefli et al. (2007). Changes in the daily runoff regime as the reduction of the peak discharge and the shift toward earlier in season are ascertained by both studies. However, a direct comparison is not possible, because (1) different climate scenarios were used, and (2) the investigated catchments differ in their extent.

\section{Conclusions}

In this study we combined results from extensive GPR measurements with an ice-thickness estimation approach (Farinotti et al., 2009b), for determining the present ice 
volume in the Mauvoisin area. A total ice volume of $3.69 \pm$ $0.31 \mathrm{~km}^{3}$ was calculated by including all available measurements, and a maximal ice thickness of $291 \mathrm{~m}$ was found. The derived ice volume distribution served as input for a combined glacio-hydrological model (Huss et al., 2008b; Farinotti et al., 2012), by which glacier and runoff projections were determined. By means of a sensitivity analysis, we could demonstrate that an under- or overestimation of the total ice volume may lead to severe distortions of the runoff projections and potentially even to deviations from the projected general runoff trend. Particularly for projections for the next 20 to $30 \mathrm{yr}$, an accurate ice volume determination and an appropriate ice-thickness distribution is crucial. The study emphasizes the importance of the incorporation or GPR measurements in order to get reliable ice-thickness distributions. Including ice-thickness measurements clearly increases the accuracy of the ice volume estimation and, hence, the runoff projections.

According to our model, the annual runoff will rise about $4 \%$ to a maximum of $275 \mathrm{mio} \mathrm{m}^{3} \mathrm{a}^{-1}$ until around 2030 and will drop in the subsequent period to $207 \mathrm{mio} \mathrm{m}^{3} \mathrm{a}^{-1}$ by 2100 . The runoff regime is expected to change from an ice melt- to a snowmelt-dominated regime. Maximum mean daily runoff will decrease from $28 \mathrm{~m}^{3} \mathrm{~s}^{-1}$ to $18 \mathrm{~m}^{3} \mathrm{~s}^{-1}$ from 2010 to 2100 and will occur 1.5 month earlier by 2100 than in the reference period.

Application of helicopter-based radar measurements on further alpine catchments will lead to a more profound knowledge about the ice volume and the ice-thickness distribution in the Alps. According to an improved knowledge about the ice volume distribution, glacio-hydrological projections will become more accurate. Progress in model approaches (e.g. knowledge of the long-term behaviour of model parameters) and the development of improved climate scenarios may further reduce the uncertainty about the future evolution.

Acknowledgements. Our particular thanks go to the Forces Motrices de Mauvoisin SA which has enabled and supported different data acquisitions in the Mauvoisin region. They have also provided long-term measurement series of the inflow to the reservoir. Further, we thank the Center for Climate Systems Modeling (C2SM) which provided regional climate scenarios of FUGE project. Constructive comments of two anonymous reviewers helped to improve the manuscript. Finally, we would like to acknowledge Bruno Nendela and Hermann Bösch for topographic and photogrammetrical analysis. This study is a contribution to NRP 61.

Edited by: M. Weiler

\section{References}

Bauder, A.: Automatic surveying for hazard prevention on Glacier de Giétro, in: Milestones in Physical Glaciology From the Pioneers to a Modern Science, Vol. 180, 1-3, Mitteilung der Versuchsanstalt für Wasserbau Hydrologie und Glaziologie, ETH Zürich, International Glaciological Symposium held in honor of Prof. Dr. Hans Röthlisberger on the occasion of his 80th birthday, 14 February 2003.

Bauder, A., Funk, M., and Huss, M.: Ice volume changes of selected glaciers in the Swiss Alps since the end of the 19th century, Ann. Glaciol., 46, 145-149, 2007.

Begert, M., Schlegel, T., and Krichhofer, W.: Homogeneous temperature and precipitation series of Switzerland from 1864 to 2000, Int. J. Climatol., 25, 65-80, 2005.

Bosshard, T., Kotlarski, S., Ewen, T., and Schär, C.: Spectral representation of the annual cycle in the climate change signal, Hydrol. Earth Syst. Sci., 15, 2777-2788, doi:10.5194/hess-15-27772011, 2011.

Braun, L. N., Weber, M., and Schulz, M.: Consequences of climate change for runoff from Alpine regions, Ann. Glaciol., 31, 19-25, 2000.

Bundesamt für Energie: Engergieperspektiven für die Schweiz bis 2050, Departement für Umwelt, Verkehr, Energie und Kommunikation, Bundesamt für Energie BFE, Switzerland, available at: http://www.bfe.admin.ch (last access: 26 November 2012), $2011 \mathrm{a}$.

Bundesamt für Energie: Wasserkraft, Departement für Umwelt, Verkehr, Energie und Kommunikation, Bundesamt für Energie BFE, Switzerland, available at: http://www.bfe.admin.ch (last access: 26 November 2012), 2011 b.

CH2011: Swiss Climate Change Scenarios CH2011, published by C2SM, MeteoSwiss, ETH, NCCR Climate, and OcCC, Zurich, Switzerland, 88 pp., 2011.

Chen, J. and Ohmura, A.: Estimation of Alpine glacier water resources and their change since the 1870s, in: Hydrology in Mountainous Regions I, 127-135, IAHS, proceedings of two Lausanne Symposia, No. 193, 1990.

Dadic, R., Mott, R., Lehning, M., and Burlando, P.: Wind influence on snow depth distribution and accumulation over glaciers, J. Geophys. Res., 115, F01012, doi:10.1029/2009JF001261, 2010.

Farinotti, D., Huss, M., Bauder, A., and Funk, M.: An estimate of the glacier ice volume in the Swiss Alps, Global Planet. Change, 68, 225-231, doi:10.1016/j.gloplacha.2009.05.004, 2009a.

Farinotti, D., Huss, M., Bauder, A., Funk, M., and Truffer, M.: A method to estimate ice volume and ice thickness distribution of alpine glaciers, J. Glaciol., 55, 422-430, 2009b.

Farinotti, D., Usselmann, S., Huss, M., Bauder, A., and Funk, M.: The runoff evolution in the Swiss Alps: Projections for selected high-alpine catchments based on ENSEMBLES scenarios, Hydrol. Process., 26, 1909-1924, doi:10.1002/hyp.8276, 2012.

Fischer, A.: Calculation of glacier volume from sparse ice-thickness data, applied to Schaufelferner, Austria, J. Glaciol., 55, 453-460, 2009.

Glen, J. W.: The creep of polycrystalline ice, P. R. Soc. Lond. A, 228, 519-538, 1955.

Hock, R.: A distributed temperature-index ice- and snowmelt model including potential direct solar radiation, J. Glaciol., 45, 101$111,1999$. 
Hock, R., Jansson, P., and Braun, L. N.: Modelling the response of mountain glacier discharge to climate warming, in: Global Change and Mountain Regions (An Overview of Current Knowledge), edited by: Huber, U. M., Bugmann, H. K. M., and Reasoner, M. A., Adv. Glob. Change Res., 23, 243-252, Springer, 2005.

Horton, P., Schaefli, B., Hingray, B., Mezghani, A., and Musy, A.: Assessment of climate change impacts on Alpine discharge regimes with climate model uncertainty, Hydrol. Process., 20912109, doi:10.1002/hyp.6197, 2006.

Huss, M., Bauder, A., Funk, M., and Hock, R.: Determination of the seasonal mass balance of four Alpine glaciers since 1865, J. Geophys. Res., 113, F01015, doi:10.1029/2007JF000803, 2008a.

Huss, M., Farinotti, D., Bauder, A., and Funk, M.: Modelling runoff from highly glacierized alpine drainage basins in a changing climate, Hydrol. Process., 22, 3888-3902, doi:10.1002/hyp.7055, $2008 \mathrm{~b}$.

Huss, M., Funk, M., and Ohmura, A.: Strong Alpine glacier melt in the 1940s due to enhanced solar radiation, Geophys. Res. Lett., 36, doi:10.1029/2009GL040789, 2009.

Huss, M., Jouvet, G., Farinotti, D., and Bauder, A.: Future highmountain hydrology: a new parameterization of glacier retreat, Hydrol. Earth Syst. Sci., 14, 815-829, doi:10.5194/hess-14-8152010, 2010.

IPCC: IPCC Emission Scenarios (SRES), Nakicenovic N, Swart R (eds), Cambridge University Press, 570 pp., 2000.

IPCC: Climate Change 2007. The Physical Scientific Basis. Contributions of Working Group I to the Fourth Assessment Report of the Intergovernmental Panel on Climate Change, edited by: Solomon, S., Qin, D., Manning, M., Chen, Z., Marquis, M., Averyt, K.B., Tignor, M., and Miller, H.L., Cambridge University Press, Cambridge, United Kingdom and New York, NY, USA, 2007.

Jóhannesson, T., Raymond, C. F., and Waddington, E. W.: Timescale for adjustment of glaciers to changes in mass balance, $\mathrm{J}$. Glaciol., 35, 355-369, 1989.

Jost, G., Moore, R. D., Menounos, B., and Wheate, R.: Quantifying the contribution of glacier runoff to streamflow in the upper Columbia River Basin, Canada, Hydrol. Earth Syst. Sci., 16, 849-860, doi:10.5194/hess-16-849-2012, 2012.

Jouvet, G., Huss, M., Funk, M., and Blatter, H.: Modelling the retreat of Grosser Aletschgletscher, Switzerland, in a changing climate, J. Glaciol., 57, 1033-1044, 2011.

Kellerer-Pirklbauer, A.: The supraglacial debris system at the Pasterze Glacier, Austria: spatial distribution, characteristics and tranpsort of debris, Z. Geomorphol., 52, 3-25, 2008.

Klok, E. J. and Oerlemans, J.: Model study of the spatial distribution of the energy and mass balance of Morteratschgletscher, Switzerland, J. Glaciol., 48, 505-518, 2002.

Lehning, M., Loewe, H., Ryser, M., and Raderschall, N.: Inhomogeneous precipitation distribution and snow transport in steep terrain, Water Resour. Res., 44, W07404, doi:10.1029/2007WR006545, 2008.

Oerlemans, J., Giesen, R., and van den Broeken, M.: Retreating alpine glaciers: increased melt rates due to accumulation of dust (Vadret da Morteratsch, Switzerland), J. Glaciol., 55, 729-736, 2009.

Paul, F. and Linsbauer, A.: Modeling of glacier bed topography from glacier outlines, central branch lines, and a DEM, Int. J.
Geogr. Inf. Sci., 26, 1-18, doi:10.1080/13658816.2011.627859, 2012.

Paul, F., Maisch, M., Rothenbuehler, C., Hoelzle, M., and Haeberli, W.: Calculation and visualisation of future glacier extent in the Swiss Alps by means of hypsographic modelling, Global Planet. Change, 55, 343-357, 2007.

Pellicciotti, F., Brock, B. J., Strasser, U., Burlando, P., Funk, M., and Corripio, J.: An enhanced temperature-index glacier melt model including the shortwave radiation balance: development and testing for Haut Glacier d'Arolla, Switzerland, J. Glaciol., 51, 573587, 2005.

Popovnin, V. and Rozova, A.: Influence of sub-debris thawing on ablation and runoff of the Djankuat Glacier in the Caucasus, Nord. Hydrol., 33, 75-94, 2002.

Radar Systemtechnik GmbH: Website, available at: http://www. rst-group.biz (last access: 26 November 2012), 2012.

Reid, T. and Brock, B.: An energy-balance model for debris-covered glaciers including heat conduction through the debris layer, J. Glaciol., 56, 903-916, 2010.

Schaefli, B., Hingray, B., and Musy, A.: Climate change and hydropower production in the Swiss Alps: quantification of potential impacts and related modelling uncertainties, Hydrol. Earth Syst. Sci., 11, 1191-1205, doi:10.5194/hess-11-11912007, 2007.

Schneeberger, C., Blatter, H., Abe-Ouchi, A., and Wild, M.: Modelling changes in the mass balance of glaciers of the northern hemisphere for a transient $2 \mathrm{CO}_{2}$ scenario, J. Hydrol., 282, 145163, doi:10.1016/S0022-1694(03)00260-9, 2003.

Schwarb, M., Daly, C., Frei, C., and Schär, C.: The mean annual and seasonal precipitation throughout the European Alps 1971-1990, Vol. 2-6, 2-7, Hydrological Atlas of Switzerland, 2001.

Stahl, K., Moore, R. D., Shea, J. M., Hutchinson, D., and Cannon, A. J.: Coupled modelling of glacier and streamflow response to future climate scenarios, Water Resour. Res., 44, W02422, doi:10.1029/2007WR005956, 2008.

Stokes, C., Popovnin, V., Aleynikov, S., Gurney, S., and Shahgedanova, M.: Recent glacier retreat in the Caucasus Mountains, Russia, and associated increase in supraglacial debris cover and supra-/proglacial lake development, J. Glaciol., 55, 444-452, 2009.

Uhlmann, B., Jordan, F., and Beniston, M.: Modelling runoff in a Swiss glacierized catchment - Part II: daily discharge and glacier evolution in the Findelen basin in a progressively warmer climate, Int. J. Climatol., online first: doi:10.1002/joc.3516, 2012.

van der Linden, P. and Mitchell, J.: ENSEMBLES: Climate Change and its Impacts: Summery of research and results from the ENSEMBLES project, Met Office Hadley Centre, Exeter EX1 3PB, UK, 160 pp., 2009.

VAW: Mauvoisin - Giétrogletscher - Corbassièregletscher. Glaziologische Studien im Zusammenhang mit den Stauanlagen Mauvoisin, im Auftrag der Elektrizitätsgesellschaft Lauffenburg AG (M. Funk, unveröffentlicht), 1998.

Verbunt, M., Gurtz, J., Jaspera, K., Langa, H., P., W., and Zappa, M.: The hydrological role of snow and glaciers in alpine river basins and their distributed modeling, J. Hydrol., 282, 36-55, 2003.

Vieli, A., Funk, M., and Blatter, H.: Griesgletscher: Berechnungen des Gletscherfliessens und Perspektiven für die Zukunft, Wasser Energie Luft, 89, 107-114, 1997. 